Research Article

\title{
An Impact Assessment of the National Policy on Guidelines and Standards for Environmental Pollution Control in Nigeria, 1991: A Case Study of the Niger Delta
}

\author{
Dr. Korikiye Wenibowei \\ The Department Of Polititcal Science, Isaac Jasper Boro College Of Education, Sagbama
}

\begin{abstract}
Oil exploration and exploitation has been on-going in the Niger Delta region in several decades. This has had disastrous effects on the region's biodiversity and socio-economic environment. More importantly, the peoples' sources of livelihood have been greatly affected due to pollution resulting from gas flaring and oil spills from explorative and exploitative activities. In the face of all these, there are existing laws and policies aimed at controlling and preserving the environment from total destruction. The main focus of this paper is the evaluation of the impact of the national policy on environment particularly the Federal Government Policy on the "Guidelines and Standards for Environmental Pollution Control, 1991" as a regulatory instrument for environmental management in Nigeria. The findings based on secondary data reveals that policies as guiding principles and regulations are essential but the enforcement of these policies have not been effective enough to attain the desired objectives for which they are enacted. The paper posits that the lack of enforcement of the policy on the guidelines and standards for environmental pollution control in Nigeria in the Niger Delta region has resulted in the continuous degradation of the region's environment, producing very severe hardship on the people as this directly affect the economic sources of survival. The country's dependence on crude oil revenue buttresses the lackluster approach by the government to environment law enforcement in the Niger Delta region. Thus, oil spillages and gas flaring is continuing in the Niger Delta region.
\end{abstract}

Keywords: Public Policy, Environment, Environmental degradation, Pollution, Gas Faring and Niger Delta.

\section{Introduction}

The emergence of the industrial revolution in the 16 th and $17^{\text {th }}$ centuries in Europe and the constituent growth of the modern Nation-State have had profound impact on man's environment. The quest for industrialization precipitated the need for the discovery of new sources of production either as substitutes or complements to existing sources (Anago, 2002). In the same vein, the growth of the modern state in the world system gave rise to economic interdependence necessitating the increase in explorative and exploitative activities. Consequently, developing countries like Nigeria, in a bid to facilitate development through industrialization encouraged and promoted explorative activities in their countries. However, these activities rather than bring about benefits to the native residents of these environments are found causing more damages to the environment and more hardship to inhabitants of such areas (Offiong, 2011).

Nigeria like most developing nations of the world, organized its economic development through several development plans primarily aimed at rapid industrialization. This phenomenon facilitated the development of critical infrastructures especially in the areas of transportation, creation of industrial complexes, engineering facilities such as steel plants, refining and petro-chemical industries as well as hydro and thermal power plants (Garba, 2001). However in the Niger Delta the hub of crude oil production, the petroleum industry and the activities of multinational oil companies have had negative effects on its environment. The Niger Delta environment resulting from oil explorative activities has "become one of the most petroleum and gas polluted environment in the world" (Offiong, 2011). Its dimensions include oil spillage leading to (water, noise, air and land pollution), gas flaring, and dumping of refuse and toxic wastes. These resultant oil explorative and exploitative activities have acted with other environmental stresses to cause damages to the ecosystem and at the same time has severely compromise the conditions of living of the people.

In recognition of these severe threats to the Nigerian environment in general, the Federal Government of Nigeria at different times have enacted environmentally related policies and legal instruments aimed at addressing the problems. Such policies and legal instruments like the oil pipeline act of 1958 , the endangered species decree of 1990, the environmental impact assessment decree 1992, the 1991 guidelines and standards for environmental pollution and control law, and others. Despite the existence of all these legal frameworks, the Nigerian environment generally, the Niger Delta region particularly continue to suffer from environmental deterioration and other forms of environment abuses carried out by registered companies. This study therefore is carried out to assess the impact of these policies in the Niger Delta region, though with specific focus on the 1991 guidelines and standards for environment pollution and control policy of the federal government of Nigeria.

\section{Statement of Problem}

The deterioration of the environment through chemical effluents by the activities of industrial plants and the consequent threat to human, plants, aquatic and animal life have attracted global attention. It has also created more 


\section{Dr. Korikiye Wenibowei / An Impact Assessment of the National Policy on Guidelines and Standards for Environmental Pollution Control in Nigeria, 1991: A Case Study of the Niger Delta}

awareness in indigenous persons in areas where these activities occur without control and mitigations. Anago (2002), for example, observed that since the 1972 Stockholm's United Nations Conference on the Human Environment, environmental issues have become transnational. Threat. to wide life, the ecosystem, fauna and flora and indeed the security of human life has made individuals and organizations in the world to undertake steps towards the protection and preservation of the environment.

Apart from the Stockholm Conference of 1972, the 1992 United Nations Conference on Environment and Development, otherwise known as the "Earth Summit" in iRio De Jeneiro has helped to generate an action plan for sustainable development of the environment in the $21^{\text {st }}$ century (Anago, 2002; Isah 2012). These Conferences and Summits and the consequent action plans and protocols provide for many countries the instrument that drives environmental protection and conservation policies, programmes and legal frameworks. For example, Nigeria in recognition of some of these international protocols and the need to provide international environmental standards and practices, the Nigerian government in 1988 established the Federal Environmental Protection Agency (FEPA) now known as the Federal Ministry of Environment (FME) (Aboribo, 2010; Boadu, Opolu-Ware and Stephens, 2010; Imasuen, 2010). The FEPA is the regulatory institution charged with the overall responsibility of protecting and developing the Nigerian environment (Offiong, 2011). FEPA came up with a national policy in 1989. The policy was meant to achieve the following objectives:

Securing the quality of the environment for health and well being.

- Conserving and using the environment and natural resources for the benefit of present and feature generations.

- Restoring, maintaining and enhancing the ecosystem and ecological processes essential for the functioning of biosphere to preserve biological diversity and the principle of optimum sustainable yield in the use of natural resources.

- Promoting public awareness on the link between development and the environment; and

- International cooperation with countries and international organizations in the protection of the environment (Anago, 2002:5).

Therefore the main goal of the national policy was to ensure the protection and preservation of the environment for human, aquatic, plants and animal habitation. Thus, it was promulgated to impose some restrains and control over individuals and corporate entities, to ensure good environmental practices in Nigeria. The position of this study is that, environmental policies and regulations are essential as guilds and regulatory instruments for the management and preservation of our environment. And Nigeria is not lacking in terms of environmental policies and laws. However, the bone of contention here is the problems of enforcement of the existing regulatory instruments to ensure safe environment whether in the Niger Delta region or elsewhere in Nigeria. It is against this background that the study is set out to achieve the following objectives.

To examine the causes and effects of environmental degradation in the Niger Delta.

To undertake an overview of the 1991 guidelines and standards for environmental pollution and control policy of the federal government.

To assess its enforcement in the oil rich region of the Niger Delta.

Finally, the study made suggestions for effective implementation of environmental policies that will lead to better environmental practices in Nigeria.

\section{Methodology}

This paper relies on secondary data source from textbooks, journal article, newspapers and the internet/website. Most of these secondary materials are available online. The data collected from these sources are critically analyzed in line with the objectives of the paper to ensure that environmental policies are implemented to achieve the desired goals.

\section{Conceptual Clarification}

Public Policy: The term public policy has been defined by several scholars and therefore, it may be futile trying to ascertain which is correct or more suitable. However, the definition given by Dye (1972:1) needs to be cited. According to him, public policy is "what government chooses to do or not to do". In practice government does a lot of things. It regulates conflicts arising from varying demands and conflicts between nations, it distributes symbolic and material rewards to members of the society, levy taxes on its citizens for the purposes of revenue generation and several other things are done through public policy instrument (Paki and Ebienfa 2011). Thus, public policy may be used to regulate behaviour, organized the bureaucracy, distribute and redistribute the wealth of the nation and even extract benefits from the citizens through the imposition of taxes (Paki an Ebienfa, 2011). These are some of the things government may do in society. But Dye (1972) is of the view that public policy also includes those things government chooses not to do. This boils down to decision making. For a government to take the decision not to do a thing or not to make changes is in itself a policy, owing to the fact that the government at that material point in time favours the continuation of the status quo.

Public policies are found in nation's laws or in public statements or pronouncements by functionaries of government. This informed Egonmwan (2004) to view public policy as a government programme of action which stands for various degrees of goal articulation and normative and how it intends to do it. This meaning of public policy laid emphasis on the action part of government, its programmes and how its goals can be achieved through policy instrument. In the same vein Shankansy (1970) and (Leicher, 1975) emphasizes the action part of government as prerequisite in the definition of 
public policy.

From whatever angle we want to look at it, public policy simply means the statement of action of government on what it intends to do, how it wants to do it and how it goes about to achieve its intentions. Therefore, an adopted environmental policy is only a statement of intentions, expectations, goals, presumptions, standards and requirements government intends to achieve in the environmental sector. In this regards, the government will need enforcement mechanisms to effectively implement it.

Environmental Degradation: By environment it means the "totality of the components of relief, vegetation, atmosphere and hydrosphere" (Aboribo, 2010). Hagget sees it as "the sum total of all conditions that surround man at any point in time on the earth's surface" (Hagget cited in Aboribo, 2011). The environment may also be referred to the physical and social conditions where people live. Jain (1977) consider the environment as being made up of both biophysical and socioeconomic elements which does not only include areas of land, air, water, plants and animals, but also other natural and manmodified features which constitute the totality of man's surroundings.

Thus, environment is the totality of our surroundings which includes every component within and around us that affects or influences our conditions of living and vice versa. This shows that there is a relationship between man and his environment. This relationship between man and his environment have resulted in some negative effects both on the environment and man's living conditions. Those negative effects on the environment owing to man's activities are what are referred to environmental degradation. Thus, environmental degradation connotes the deterioration of the physical environment through the activities of man by the displacement of "natural landmarks and the introduction of pollutants, which in turn affects the air, water and land, thereby endangering the life of organisms including human lives" (Offiong, 2011; 423).

\section{Causes and Effects of Pollution and Gas Flaring in the Niger Delta}

The Niger Delta region is known for its rich natural resources. Foremost amongst these is its large reserve in hydrocarbon. The region accounts for 2.3million barrels of crude oil production per day (NNPC, 2013). Nigeria is ranked the largest oil producing country in Africa and $11^{\text {th }}$ largest in the world (NNPC, 2013). Reports suggest that there are over 150 oil fields and over 1481 oil wells locations in the region that situates the region as the largest oil reserve in the continent and $10^{\text {th }}$ in the world (Isah, 2012). The country presently derives over $90 \%$ of its revenue from crude oil and gas (Ojukwu - Ogba, 2009). This may explain the importance of the sector to the nation's economy. Nevertheless, this success in the oil and gas sector is achieved not without a price. The price been the level of environmental degradation caused by constant oil spills and the uncontrolled gas flaring in the region.

\section{Environmental Pollution Caused by Oil Spillage}

The worst and most obvious forms of pollutions in the Niger Delta are oil spillage and gas flaring. Oil spillage occurs due to a number of causes including corrosion of pipelines and tankers (accounting for 50\% of all spills), sabotage (25\%) and oil production operations $(21 \%)$, with $1 \%$ of the spills being accounted for by inadequate or non-functional production equipment, according to The Association of Environmental Health and Science (AEHS, 2006). Invariably, oil spill is a major environmental concern in the region as it adversely affects the people and the entire ecosystem.

Table. 1: Showing oil spill incidence from January to December 2014

\begin{tabular}{|c|c|c|c|c|c|c|c|}
\hline Month & $\begin{array}{c}\text { Natural } \\
\text { Accident }\end{array}$ & Corrosion & $\begin{array}{c}\text { Equipment } \\
\text { Failure }\end{array}$ & Sabotage & $\begin{array}{c}\text { Human } \\
\text { Error }\end{array}$ & $\begin{array}{c}\text { Total } \\
\text { Number of } \\
\text { Spills }\end{array}$ & Vol. of Spilled oil \\
\hline Jan & 0 & 6 & 5 & 86 & 1 & 117 & 17 \\
\hline Feb & 0 & 5 & 4 & 67 & 0 & 100 & 168.26 \\
\hline March & 0 & 3 & 7 & 63 & 1 & 98 & 269.91 \\
\hline April & 1 & 4 & 9 & 98 & 2 & 134 & 465.15 \\
\hline May & 2 & 1 & 8 & 90 & 0 & 117 & 690.42 \\
\hline June & 1 & 7 & 7 & 49 & 2 & 90 & 194.47 \\
\hline July & 1 & 5 & 21 & 53 & 1 & 103 & 711.79 \\
\hline Aug & 1 & 4 & 8 & 50 & 0 & 74 & 1578.86 \\
\hline Sept & 1 & 0 & 8 & 55 & 0 & 77 & 159.14 \\
\hline Oct & 0 & 1 & 8 & 22 & 1 & 45 & 427.60 \\
\hline Nov & 5 & 4 & 6 & 39 & 0 & 76 & 5224.36 \\
\hline Dec & 0 & 2 & 3 & 36 & 0 & 56 & 27.25 \\
\hline Total & 12 & 42 & 94 & 708 & 8 & 1,087 & $10,302.16$ \\
\hline
\end{tabular}

\section{Source: Nigerian National Petroleum Corporation Annual Statistical Bulletin, 2015}

The NNPC places the quantity of oil jettisoned into the environment yearly at 2,300 cubic meters with an average of 300 individual spills annually, according to The Association of
Environment Health and Science (AEHS). Flowing from the above, there is no doubt that oil spillage constitutes large proportion of environmental pollution in the Niger Delta. 
Thus, it constitutes grave consequences on the life and the environment of the people.

Isah (2012) for example, said that, Nigeria has had over 4,000 oil spills incidents ranging from minor oil spills of a few hundreds of barrels to over half a million barrels in a single incident. Another study indicated that an estimated 2,567,966 barrels of crude oil have been spilled in 5733 incidents in the Niger Delta from 1976-2000 and only about 549,060 barrels were recovered while about 1,820,411 barrels of spilled crude oil were lost to the environment (Ite, Ibok, Ite and Petters,2013). Brown (2006) noted that up to $1.5 \mathrm{~m}$ tons of oil, 50 times more than the pollution caused by the Exxon Valdex tanker disaster has been spilt in the ecological system in the Niger Delta region over a 50 year period (1956-2006). Ugo and Ukpere (2012) in their view, indicate that the cost of the leaking crude was estimated to be around $\$ 10$ million per year. Gas flaring is the second environmental consequence concomitant to the oil economy in the Niger Delta beside oil spillage (See figure II, showing a gas flaring site). Equally damaging and dangerous as oil spillage, gas flaring has been continuing in the region since petroleum refining activities started in the area. In the Niger Delta, gas flaring constitutes a bigger problem to the region's environment. A World Bank Report indicated that Nigeria presently is ranked seventh in terms of countries with the highest volume of gas flares (World Bank Report, 2017). In 2013, Nigeria was ranked second after Russia as the highest gas flaring nation in the world.

Table 2: showing countries that are major gas producers and the degree of gas flares in these countries.

\begin{tabular}{|l|l|}
\hline Country & $\begin{array}{l}\text { Gas Flares in Billion Cubic } \\
\text { Meters Annually }\end{array}$ \\
\hline Russia & 21.0 Billion \\
\hline Iraq & 16.0 Billion \\
\hline Iran & 12.5 Billion \\
\hline United States & 12.0 Billion \\
\hline Venezuela & 10.0 Billion \\
\hline Algeria & 9.5 Billion \\
\hline Nigeria & 9.0 Billion \\
\hline Mexico & 5.5 Billion \\
\hline Angola & 5.0 Billion \\
\hline
\end{tabular}

The new ranking - top 30 flaring countries (2013-15)

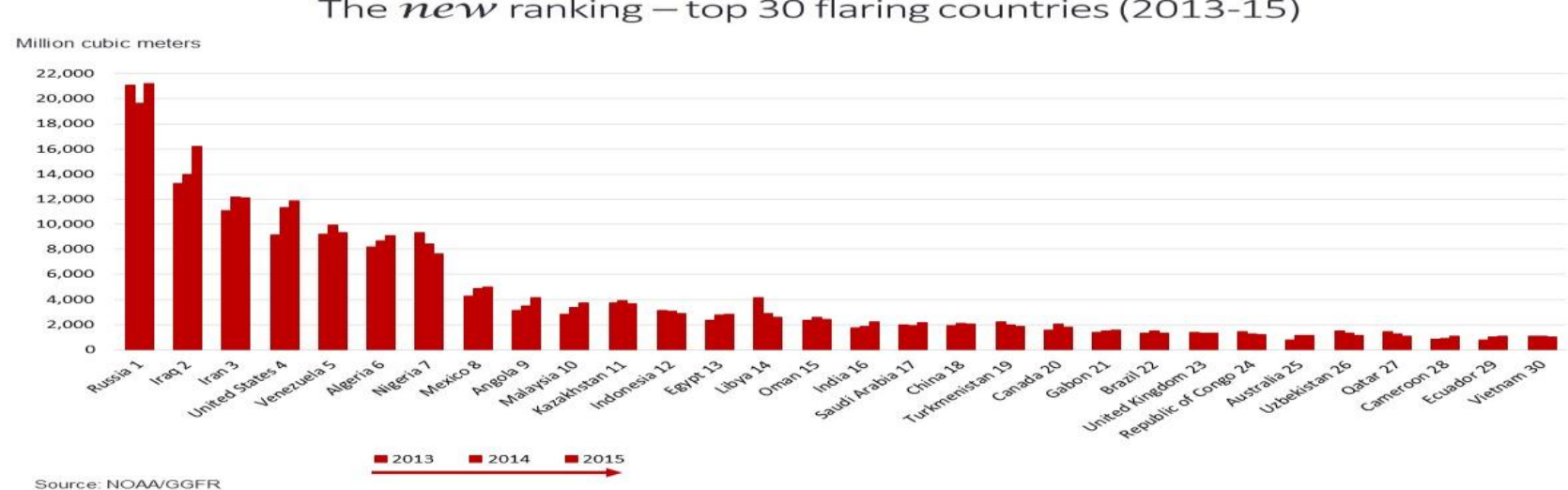

SOUrce: NOANGGFR

\section{Source: World Bank Report, 2017}

Nigeria in the last 10 years dropped being the second highest gas flaring nation in the world to occupy the seventh position (See figure I, showing the new ranking of the top 30 gas flaring countries of the world). Nigerian National Petroleum Corporation's (NNPC) statement from his Group General Manager, Public Affairs, Mr. Ndu Ughamadu has that "Nigeria between 2006 and 2016, succeeded in reducing gas flare from her oil and gas fields by 26 percent within the 10 years period" (Thisday Online, 2017). The report further stated that, from 36 percent flare rate, it recorded only 10 percent of gas flare from her fields in the Niger Delta region. Corroborating the NNPC report is the report of the World Bank's Global Gas Flaring Reduction Partnership (GGFR), which indicated that as at the end of 2015, Russia, Iraq, Iran, United States, Venezuela and Algeria were the six other countries ahead of Nigeria in global gas flaring (Thisday, Online, 2017). Usman (2008) noted that Nigeria produced an estimated 3.5 billion cubic feet $(100,000,000 \mathrm{~m})$ of associated gas annually, out of this amount 2.5 billion cubic feet $(70,000,000 \mathrm{~m})$ or about $70 \%$ of it is wasted via flaring.

In the Niger Delta region there are about 123 gas flaring sites (Ayuba, 2012). Agbola and Olurin (2003) argued that, about 45.8 billon kilo watts of heat is discharged into the atmosphere from 1.8 billion cubic feet of gas daily in the Niger Delta generating temperature that render large areas uninhabitable. Nigeria National Petroleum Corporation (NNPC) annual report of 2014 stated that the independent oil and gas firms and marginal field operations in the country burnt over 90 percent of the national gas produced on their fields in the fourth quarter of that year (The Environmental Outreach, 2015:41). The firms that are engaged in these ghastly activities include Nigerian Petroleum Development Company (NPDC), a subsidiary of the NNPC; Seplat Petroleum Development Company (SPDC), First Hydrocarbon, (FH); Niger Delta Western, Naconde, Amni International, Midwestern Oil and Gas, Niger Delta Petroleum, and Walter Smith. There are basically three major operators in the gas industry. These major groups are the International Oil Companies (OICs) like Shell, Total and Chevron; the Joint Venture Parties and the Marginal Field Operators. 


\section{Dr. Korikiye Wenibowei / An Impact Assessment of the National Policy on Guidelines and Standards for Environmental Pollution Control in Nigeria, 1991: A Case Study of the Niger Delta}

Both oil spillage and gas flaring are caused by oil explorative and exploitative activities. Therefore, in the Niger Delta the major cause of environmental degradation comes from the oil industry. The major forms are oil spills and gas flaring. The environmental effects of oil spillage and gas flaring are air, land and water pollution. In the Niger Delta, the fundamental environmental problem therefore is pollution caused by oil spillage and gas flaring. The region is one of the most polluted regions in the world today.

Figure 2: Gas flaring site

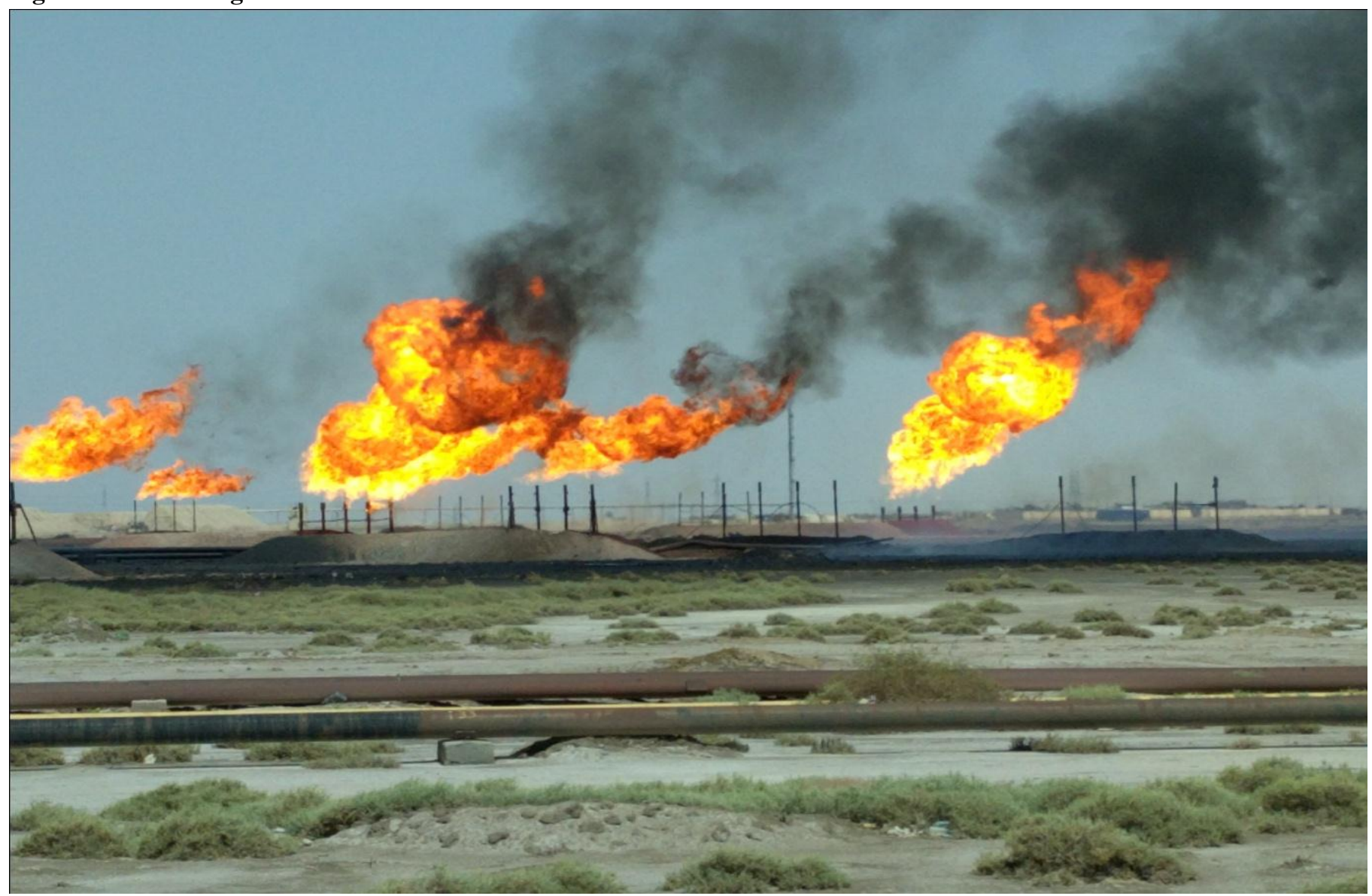

\section{Source: World Bank Report, 2017.}

Oil spill incidents associated with oil exploration and exploitative activities are common in Niger Delta and have constituted environmental degradation in host communities in the region.

Regarding the level of environmental degradation, the consequences are numerous and multidimensional in nature. Oil exploration and exploitation have caused enormous damage to human, animal, plants and aquatic life. The manifestation of environment degradation takes varying dimensions. Tables 3 below show some of the effects of oilrelated pollution on land, air, water and on human life.

\section{Table 3: The environmental effects of oil pollution}

\begin{tabular}{|l|l|}
\hline 1 & Pollution of water bodies \\
\hline 2 & $\begin{array}{l}\text { Pollution of rivers and loss of aquatic plants and animals due } \\
\text { to contamination }\end{array}$ \\
\hline 3 & Devastation of crops and other useful economic plants \\
\hline 4 & General environmental devastation \\
\hline 5 & Problem of visual pollution \\
\hline 6 & Massive depletion/extinction of local animal species (wildlife) \\
\hline 7 & Contamination of farm land \\
\hline 8 & Reduction in rate of litter decomposition/nutrient cycling \\
\hline 9 & other health hazards \\
\hline
\end{tabular}

Source: Imasuen (2010:31)
An Overview Of The 1991 Guidelines And Standards For Environmental Pollution And Contol Policy of The Federal Government Of Nigeria.

Environmental issues have become international concern in view of the eminent threat to human, plant, and animal life. With respect to the environment several international conventions, declarations and resolutions have been made. Some of these are;

The June 13, 1992 Rio de Jeneiro Declaration on Environment and Sustainable Development.

The Basel convention on the control of Trans-Boundary movement of Hazardous Wastes and their disposal 1989.

International convention on the establishment of an international fund for compensation of oil pollution damage (Brussel 18 December, 1971).

Declaration of the United Nation's conference on the Human environment Stockholm 16 ${ }^{\text {th }}$ June, 1972 (Ugo and Ukpere, 2012).

These and others have provided standards that are more acceptable when dealing with environmental issues. Equally too, these declarations and resolutions have provided national governments the fundamental instrument for the formulation and implementation of national policies and legal frameworks 


\section{Dr. Korikiye Wenibowei / An Impact Assessment of the National Policy on Guidelines and Standards for Environmental Pollution Control in Nigeria, 1991: A Case Study of the Niger Delta}

on the environment. Against this background, the Guidelines and Standard for Environmental Pollution Control in Nigeria, 1991 was established as an environmental management instrument for the country.

In 1991, the federal government came up with this policy providing guidelines and standards in regards to the volume of pollution industrial activities can cause in a given area. The policy directs industries in the country to improve on the quality of the environment and free it from pollution and other environmental hazards. Thus, providing recommended standards of environmental best practices in the country. The policy has six (6) key areas of environmental regulation. These are, (1) effluents limitation, (2) water quality for industrial uses at point of intake, (3) industrial emission limitation, (4) noise limitation, (5) management of solid and hazardous waste, (6) pollution abatement in industries. The Effluent Limitations Regulations policy directs all operating industries to, among other things, install anti-pollution equipment for the detoxification of it's out flowing chemicals discharges and treat the same to stipulated levels before discharging it (Anago, 2002). In other words, this regulation put limit to the volume or quantity of pollutants an industry can discharge into the environment at any given time. The Pollution Abatement Regulations law prohibits the release of hazardous or toxic substances into the environment beyond the limits approved by the agency (FEPA). It also provide for other requirements and procedures especially in cases of accidental or unusual discharges and at the same time require industries to obtain permit for discharges that are beyond permissible limits, while the Waste Management and Hazardous Waste Regulation regulates the collection, treatment and disposal of solid and hazardous waste from municipal and industrial sources and provides a comprehensive list of chemicals and chemical waste by toxicity categories. The noise limitation and the industrial emission limitation regulations are meant to reduce the level of noise and level of industrial emission in an environment.

\section{The Impact of the Policy in the Niger Delta}

With the existence of this regulatory policy and others in the Nigerian system, it is difficult for one to say that the Nigerian government has not made efforts towards the control and management of its environment. It is therefore difficult to fault the Nigerian State at the level of its intentions on issues of environmental degradation. However, in spite of these elaborate and comprehensive laws and regulations enacted by the government over the years, the situation that actually warranted their enactment has not change significantly. Ugoh and Ukpere (2012) noted that the common recourse today is that no matter what the government's intention may be, the implementation is the problem. This observation tends to lay credence to the argument that over the years the Nigerian state is known for formulating good public policies but grossly fall short when it comes to enforcement or implementation (Offiong, 2011; Anago, 2002; Aboribo, 2010; Lenusira, N.A). The increasing incidence of oil spillages and gas flaring in the region is an indication of the non compliance to the regulatory frameworks by multinational oil companies (MNOCs) and the non enforcement of the policy by the appropriate agencies. This goes on to explain the weakness of the Nigerian state in the implementation of environmental policies and regulatory frameworks. Ibaba (2010) noted that the environmental laws in Nigeria has not anyway contributed to sustainable development and has also not been able to reduce the rapid rate of environmental degradation in the Niger Delta region. He attributed this condition to the lack of enforcement of the laws by appropriate institutions and agencies.

For instance, Agbola and Olurin (2003) noted that about 45.8 billion kilo watts of heat are discharged into the atmosphere from 1.8 billion cubic feet of gas daily in the Niger Delta region, rendering large areas of the region unsuitable for human habitation. In 2004, Nigerian Liquefied Natural Gas pipeline traversing through Kala-Akama, in Okrika mangrove forest leaked for three days and was later set ablaze (Nenibarini,2004) resulting in the destruction of plants and animals within the area.

Giving the above situation, the position of this paper is that, as long as oil spillage and gas flaring continuous and no adequate measures are taken to abate or punish defaulters, environmental policies have not impacted positively on the Niger Delta environment. In other words, governmental agencies such as Federal Environmental Protection Agency(FEPA) now the National Environmental Standards and Regulations Enforcement Agency(NERSEA), Ministry of Environment and the Nigerian National Petroleum Corporation(NNPC) lacks the necessary political will and the technical know-how to effectively and efficiently enforce environmental policies in Nigeria. Statutory provisions and regulations which are meant to protect the environment are breach with impunity by oil companies and yet nothing is been done by the government and its institutions.

Several reasons have been given for the inability of the government and its agencies to adequately enforce environmental laws in Nigeria. Some of them include corruption, the conflicting or overlapping roles of government institutions and agencies, lack of technical manpower for assessment of damages, lack of adequate funding of institutions and agencies, divide and rule tactics of multinational companies especially in the Niger Delta area, and the country's dependency on crude oil. This present study accepts and recognizes all these factors as obstacles to the effective implementation of the laws. Nevertheless, this study is of the opinion that the economic factor is most crucial to the understanding of the non compliance and non enforcement of environmental policies in Nigeria. The Nigerian economy depends largely on crude oil and gas.

The discovery of crude oil did not just displace interest on other sectors of the country's economy, but also made crude oil as mainstay of the Nigerian economy. Edo (2012) observation in regards to the contribution of the oil and gas sector between 1970 and 2008 need to be cited here. According to him;

As at 2008, the dominance of crude oil sector has been well 


\section{Dr. Korikiye Wenibowei / An Impact Assessment of the National Policy on Guidelines and Standards for Environmental Pollution Control in Nigeria, 1991: A Case Study of the Niger Delta}

established, and the sector accounted for over 82 percent of government revenue from a meager contribution of 26.1 percent in 1970. In the same period, the gas and oil sector account for 99 percent of the total export earnings in 2008(Edo, 2012:269)

Similarly, Mbachu (2012, cited in Edo, 2012) noted that;

The contribution of crude oil and gas to government revenue not only underlines the centrality of revenue from the industry to financial viability of the Nigerian state, it also shows the importance of oil rent in national politics.

It is noteworthy to say therefore that, for a sector that has been instrumental to the nation's economy providing more than 90 percent of the total revenue earnings and more than 82 percent recurrent revenue, and the other sectors contributing almost nothing, it becomes apparent that the government will have double standards in the enforcement of critical laws that may have adverse effect on its incomes. Undoubtedly then, it will be invariably difficult for the Nigerian state to enforce environmentally related regulations that could hamper production of oil and gas whose proceeds it need to drive growth and development. Therefore a strict application of the environmental policies and laws will no doubt adversely affect the income of the nation. This fact remains a fundamental obstacle to the effective implementation of the environmental policies in the Niger Delta region.

\section{Recommendations}

There should be periodic environmental audit aimed at ensuring compliance with environmental practices and laws. This can be achieved through objective evaluation of operations related to the environment by private and corporate entities and so on.

Agencies or institutions saddled with the control and management of the environment should be properly and adequately supported through adequate funding, provision of adequate equipment for assessment and the engagement of professionals. In this regards, budgeting allocations to such agencies should be released promptly. Also, regular training and staff development should be a priority for the government to consistently update and upgrade the knowledge of experts in the field.

Areas of jurisdictional conflicts between agencies or departments should be identified and clear. Responsibilities of those involved in the management of the environment should be clearly spelt out to prevent conflicts.

Nigeria should live up to its promise to end gas flaring in the Niger Delta and elsewhere in the country.

\section{Conclusion}

Obviously, it is important to acknowledge the fact that the Nigeria state has taken steps to formulate and implement environmental policies and legal frameworks aimed at ensuring better environmental practices by private and corporate organizations. While the appropriateness of these policies and laws may be difficult to be faulted, their effective implementation aimed at providing better environment for human habitation is full of flaws and thus has render most of these laws impotent especially in the Niger Delta region. The main reason for the ineffective implementation is that oil and gas remains the major source of revenue to the Nigerian government. Therefore, the full implementation of the policy on the environment will no doubt reduce the income of the nation. For this reason, the Nigerian State has become more concerned with its economic interest rather than create a conducive and acceptable atmosphere for human habitation.

\section{References}

[1] Aboribo, R. I (2010), Oil Spillage, Environmental Degradation and the interpretive Framework of Globalization, volume 3, Number 1.

[2] Agbola, T and Olurin, T.A (2003): Landuse and Landcover Change in the Niger Delta. Excerpts from a Research Report presented to the Centre for Democracy and Development

[3] Anago, I (2002), Environmental Impact Assessment as a tool for Sustainable Development: the Nigerian Experience. FIGXXII International congress, Washington DC April 1-26.

[4] Ayuba, K. A (2012). "Environmental Impacts of Oil Exploration and Exploitation in the Niger Delta of Nigeria". Global Journal of Science Frontier research. Volume 12, issue version 1.0

[5] Boadu, M. A Opolu-Ware, E and Stephens, T (2010), Environment and social challenges in oil sector management international journal of environmental science volume 6 , number 3

[6] Dye, T. (1975) cited in Paki and Ebienfa (2011) Ibid

[7] Edo (2012): The Challenges of Effective Environmental Enforcement and Compliance in the Niger Delta Region of Nigeria. Journal of Sustainable Development in Africa. Volume 14, No.6. Clarion University of Pennsylvania.

[8] Egonmwan (2000): Public Policy Analysis: Concepts and Applications. Revised Edition. Benin City. Ambik Press

[9] Garba, H. L (2001), Sustainable Industrial Development in a Developing Economy-Nigeria: Nigerian Journal of Industrial Pollution vol. 1.

[10] Ibaba,S.I (2010): "Environmental Protection Laws and Sustainable Development in the Niger Delta". Africana. Vol. 4, No.1. June.

[11] Imasuen M. O (2010), "The environmental impact of oil spillage in the Niger Delta" International Journal of Environmental Science, volume 6 number 3.

[12] Isah, M.N (2012) The Role of Environmental Impact Assessment in Nigeria's Oil and Gas Industry in Lenusira.

[13]Ite, A.E; Ibok,U.J; Ite, M. U and Petters, S.W (2013):Petroleum exploration and Production: Past and Present Environmental Issues in the Ngeria's Niger Delta. Journal of Science and Education.

[14] Jain (1977) cited in Aboribo (2010) Ibid.

[15] Nigerian National Petroleum corporation (2013) http://www.nnpcgroup.com

[16]Leicher,N (1975): A Comparative Approach to Policy 
Analysis: Health Care Delivery in Four Nations. Cambridge. Cambridge University Press.

[17] Lenusira, W.E(N.A);The Role of Environmental Impact Assessment (EIA) in the Nigerian Oil and Gas Industry using the United Nation's Environmental programme. EIA on Ogoni As a case study Lessons from some international good practices. A $\mathrm{PhD}$ research proposal submitted to Cardiff university.

[18] Nigerian National Petroleum Corporation (2013) online. http://www.nnpcgroup.com

[19] Offiong,J.O(2011);The Dilemma of Implementing Effective Environmental Policies in Nigeria. www.transcampus.org/journals

[20] Ojukwu-Ogba, N.E (2009); "Legislating Development in Nigeria's Oil Producing Region: The NDDC Act Seven years on $17 \mathrm{AJICH}, 1$.

[21] Paki, A.E.F and Ebienfa, K. I (2011); "Public Policy in Nigeria: An Implementation Paradox "Journal of Social Science and Public Policy. Volume 3, March.

[22] Shankansy, I (1970): Policy Analysis in Political Science. Chicago. Markham

[23] Ugoh, S.C and Ukpere, W (2012); Environmental Policy in Nigeria: Paradox of Nigeria Delta Sustainable Devleopment. J. Hum Ecol, Volume 37, Number 3.

[24] Usman, S. (2008). Why Nigeria remains poor despite being rich in Oil in 50 years. Tell Magazine, Lagos. Special Edition. June

[25] World Bank Report (2017). The New Ranking -top 30 Flaring Countries (2013-2015). Globalgasflaring and oil production.org 